\title{
DETERMINANTS OF SOUTH AMERICAN BANK CREDIT: AN APPROACH TO PANEL DATA ${ }^{\circ}$
}

\author{
DETERMINANTES DEL CRÉDITO BANCARIO SUDAMERICANO: \\ UN ENFOQUE PARA LOS DATOS EN PANEL
}

\author{
Vitor Gomes Reginato* \\ Marina Silva da Cunha* \\ Marcos Roberto Vasconcelos*
}

enviado: 23 enero 2019 - aceptado: 27 junio 2019

\begin{abstract}
This paper aims to analyze the determinants of the domestic banking credit in South American countries, based on panel data, over the period from 2000 to 2016 . The results indicate that domestic deposits and liabilities to non-residents contribute positively to the growth of private credit, with domestic funding showing a more representative impact than foreign funding. Economic growth leads to a greater demand for credit and an increase in credit, while higher domestic and US interest rates reduce credit growth. Rising inflation also negatively affects the private sector credit. Furthermore, regarding the credit composition, domestic deposits and economic growth are the main components of credit expansion and, in turn, inflation and domestic interest rates contribute negatively.
\end{abstract}

JEL Code: G21, E44, E51.

Keywords: bank credit, data panel, South America.

Gomes Reginato, V., Cunha, M. S., \& Vasconcelos, M. R. (2020). Determinants of South American bank credit: an approach to panel data. Estudios económicos, 37 (24), 37-70.

* State University of Maringá (UEM), Brazil. E-mail: vitoreginato@hotmail.com, mscunha@uem.br, mrvasconcelos@uem.br 


\section{Resumen}

Este trabajo analizó los determinantes del crédito bancario doméstico en los países de América del Sur, con base en datos en panel, para el período de 2000 a 2016. Los resultados indican que los depósitos domésticos y las obligaciones con no residentes contribuyen positivamente al crecimiento del crédito privado. El crecimiento económico eleva la demanda de crédito y tiene como consecuencia el aumento del volumen de crédito, mientras que mayores tasas de interés, doméstica y norteamericana, reducen el crecimiento del crédito. La inflación también afecta de forma negativa al crédito del sector privado. Además, en cuanto a la composición del crédito, los depósitos domésticos y el crecimiento económico son los principales componentes de la expansión del crédito. La inflación y tasa de interés doméstica contribuyen negativamente.

Código JEL: G21, E44, E51.

Palabras clave: crédito bancario, panel de datos, América del Sur. 


\section{INTRODUCTION}

In modern economies, a large part of investment and even consumption decisions involve the search for financing, that is, it take credit. Whether it is the decision to expand productive capacity or to adopt new productive technologies, agents do not always have the necessary financial resources internally to execute these investments. Thus, the availability of credit resources ends up conditioning both the pace of aggregate demand expansion and aggregate supply itself. Knowing what factors can influence the credit trajectory in the economy is relevant and helps in understanding the possibilities of economic growth. It is in the financial markets that the determinants of demand and supply adjust and the channels of this interaction are defined. The more developed the financial market, the greater and better the credit accessibility conditions tend to be.

Therefore, in general, the credit variable in proportion to the Gross Domestic Product (GDP) is used as a proxy to measure the degree of financial development and estimate its importance for economic growth. The idea is that the provision of credit would be related to the presence of institutions specialized in financial intermediation, which would play a fundamental role in optimizing the allocation of resources in order to raise the savings rate of the economy and to increase the efficiency of investment decisions. Thus, financial intermediation carried out mainly by the banking sector plays a crucial role in the economic development of countries, especially those with underdeveloped capital markets, such as the countries of South America. Bank institutions, through loans, carry out the transfer of resources from the surplus agents to the deficit agents, enabling the financing of investments, contributing to economic growth.

Assuming the importance that the availability of bank credit has for the total credit of the main South American countries, investigating which macroeconomic variables may influence this offer helps to understand the very effective and potential dynamics of economic growth in these countries. As shown by Aghion et al. (2005), the presence of a developed financial market capable of providing credit is essential for developing countries ${ }^{1}$. Overcoming credit constraints would allow such countries to track, through technological incorporation, the growth rate of the major countries in technological progress, to keep constant the productivity gap over time. Therefore, even if the financial system were unable to finance the domestic production of new

1 According to the International Statistical Institute (ISI) classification, eight of the ten South American countries analyzed in this paper are considered developing countries in 2019 , being exceptions Chile and Uruguay. 
technologies, as assumed, for example, in King and Levine (1993) and Morales (2003), it would be an essential condition for backward countries to be able to absorb technology created externally by the most developed nations.

In fact, the relationship between financial development and economic growth remains one of the most contentious relationships in the economy. Rescuing a tradition that begins in Bagehot (1962), Hicks (1969) and Schumpeter (1997), King and Levine (1993) have shown how financial development would be an essential element for long-term economic growth. This work was followed by a series of articles pointing to the positive relationship between financial development and economic expansion, such as De Gregorio and Guidotti (1995), Levine (1997), Rajan and Zingales (1998), Levine et al. (2000), Beck et al. (2008), among others. However, following the Great Crisis of 2008, several studies, such as Aikman et al. (2014), Schularick and Taylor (2012) and Jordà et al. (2010), show the growth of credit as a precursor to financial crises and, through this channel, capable of negatively affecting long-term economic growth. Given this disparity, studies began to emerge with the hypothesis that the relationship between financial development and economic growth would not be a monotonically positive relationship, regardless of the level of financial development achieved by the economy, such as Samargandi et al. (2015) and Cecchetti and Kharroubi (2012).

According to Bernanke and Blinder (1998), banks play this role of financial intermediaries simply by considering that they are able to deal with the asymmetry of information present in the transactions. This is because they have experience and knowledge about borrowers and are able to monitor payments, which makes it possible to extend credit to those who have difficulty obtaining it directly in the market. In turn, as Levine et al. (2000) noted that an important step towards financial development is the presence of laws and regulations that strengthen the rights of creditors against debtors, minimizing the possibilities of loss in the value of bank assets. When this occurs, there is room for the banking system to expand its financing operations.

From the beginning of the 1990s, a series of institutional reforms in favor of an economy with greater liberation and financial internationalization were observed in South America countries (Aizenman, 2005; Freitas \& Prates, 1998). Among other purposes, such reforms have strengthened the debt collection mechanisms and allowed the entry of foreign banks into local markets (Vasconcelos et al., 2003; Yildirim \& Philippatos, 2007). Such changes alter the framework defined as financial repression and credit constraint experienced by such economies. Moreover, as shown in this paper, one of the consequences was a sharp rise in the credit-GDP ratio in the South American economies. 
In fact, in South America ${ }^{2}$, the total volume of bank credit grew approximately by 14.5 times between 2000 and 2016: from US\$ 132 billion in the first quarter of 2000 to US\$ 1.9 trillion in the last quarter of $2016^{3}$. Domestic deposits showed the same trend, but in a smaller magnitude, slightly more than 13 times, going from US\$ 129 billion to US\$ 1.7 trillion for the same analyzed period. This volume of credit and bank deposits may have led the economies of that region to a higher stage of financial development capable of boosting in the long term the per-capita GDP growth convergence of these economies at the level of the richer countries, as provided in the model of Aghion et al. (2005).

Therefore, in view of the likely importance of credit for economic growth, the main objective of this paper is to describe the evolution of credit operations for the private sector in South America countries and to analyze their main determinants. For this purpose, the impact generated by the macroeconomic variables considered for the study from 2000 to 2016 is evaluated. Our study contributes to the existing literature in different aspects. First, this is the first work that identifies the determinants of bank credit specifically for the major South American countries jointly. Second, the study assesses bank credit from 2000 to 2016, which allows us to examine a credit cycle in the region both in the pre-crisis expansion and in the contraction and accommodation phase in the post-crisis 2008 period. The choice of the private sector credit operations variable is aligned with the proxy used by Levine et al. (2000) as an indicator of the degree of financial development of an economy. Thus, by monitoring the evolution of private credit and its determinants in each of the South American economies, this also shows the progress in the financial development of these countries.

In addition to this introduction, which presents a brief discussion on the theme, the article is organized into six further sections. In the next section, we provide a brief overview of some of the papers dealing with credit determinants in different countries or group of countries. Then, we present the sources from which the data were extracted, the econometric method used in the study and the description of the variables. In the fourth section, the results obtained from the estimates

2 Due to lack of data, Guyana, Guyana and Suriname were excluded from the sample of the South American countries with Argentina, Bolivia, Brazil, Chile, Colombia, Ecuador, Paraguay, Peru, Uruguay and Venezuela remaining.

3 Although it is interesting to separate how much of this credit expansion was directed to consumption and to investments, for the set of countries analyzed in our work there is no database with such data at this level of disaggregation. 
are analyzed and discussed. In the fifth section, we present the robustness tests of our estimates. Finally, the last section draws policy implications and concludes.

\section{BRIEF REVIEW OF EMPIRICAL LITERATURE}

The economic literature on the determinants of bank credit is not vast. In the international environment, Guo and Stepanyan (2011) highlighted the determinants of bank credit for 38 emerging economies from 2001 to 2010, dividing their analysis into two periods; the first one from 2001 to the global crisis of 2008 and the second, the post-crisis. The authors concluded that domestic deposits and foreign liabilities contribute positively and symmetrically to economic growth, with economic growth and inflation as factors that positively impact credit. In turn, the higher basic interest rate, representing tight domestic monetary policy, and tighter US monetary policy negatively influence domestic credit.

By studying the behavior of credit operations, Kamil and Rai (2010) observed that domestic or external sources of financing were relevant during the crisis to the growth of credit operations, in which the more dependent countries on external financing were the most impacted ones. In their results for Latin America, the authors pointed out that foreign bank lending to countries included in this region corresponded to the financing constraints caused by liquidity conditions in the world interbank market and the vulnerability of banks themselves. In addition to Guo and Stepanyan (2011) and Kamil and Rai (2010), we also highlight Harbo Hansen and Sulla (2013), who considered the Latin American countries, and Cottarelli et al. (2003), who analyzed a group of countries formed by Central and Eastern Europe and the Balkans.

Some authors have investigated the determinants of bank credit for individual countries. Assefa (2014) studied the case of Ethiopia, Imran and Nishat (2013) Pakistan, Shijaku and Kalluci (2013) Albania, Albulescu (2009) Romania, Fritzer and Reiss (2008) Austria and finally Almeida and Divino (2016), Mendonça and Sachsida (2013), Fucidji and Prince (2009), Blum and Nakane (2005) and Vasconcelos et al. (2004) specifically analyzed the case of Brazil.

Using the Autoregressive Distributed Lag (ARDL) econometric approach and annual data for the period 1978 to 2012, Assefa (2014) sought to estimate the main factors to define the evolution of credit in Ethiopia. In the period under review, the country's credit-GDP ratio jumped from $5.9 \%$ to $10.4 \%$, almost all of which originated in the banking system. The results of the work of Assefa indicated 
great importance for the domestic deposits as a factor driving the credit in the country, which for him seemed to validate the loanable funds theory. As expected, GDP has a significant and positive impact. Assefa also showed a positive and statistically significant relationship between the real lending rate and credit, but contrary to the loanable funds theory, the money supply ratio (estimated by the M2 to GDP ratio) is negative. For Assefa, this may be the result of a greater concern of economic agents with future inflation, causing them to expect a decline in future real income. This explanatory hypothesis is in line with the observation of the estimated model of the presence of a negative relation between credit and past inflation. However, the author found a positive and statistically significant impact between current inflation and credit, that is, there seemed to have been a kind of monetary illusion in Ethiopia in the period covered by the study. With the use of annual data for the period 1971 to 2010, and with an ARDL model, Imram and Nishat (2012) highlighted the importance of bank credit for Pakistan's economic growth rate and estimated that this credit presents a positive relationship with the variables foreign liabilities, domestic bank deposits, GDP, exchange rate and the M2 as percentage of GDP. In turn, inflation and domestic interest rate have no statistical significance, according to the authors, possibly due to the stability of these two variables over time. Overall, the results indicate the significant importance of foreign sources of funds to the availability of bank credit in Pakistan, which, together with the relevance of domestic bank deposits, supports the loanable funds theory.

Another country that seems to have high reliance on external sources for domestic credit is Albania. This country has had the deregulated banking market since 2001, with the peak of the process occurring in 2004 with the privatization of the country's main banks and the entry of foreign financial institutions. According to Shijaku and Kalluci (2013), after this, the availability of credit in the country is boosted, thanks in great part to the large inflow of external resources. Shijaku and Kalluci (2013) used the Vector Error Correction Mechanism (VECM) model to estimate the key determinants of bank credit in Albania from 2001 to 2011. The first point highlighted by the authors is how stability and economic growth appear to favor expansion credit bank. For the authors, GDP has a strong positive relation with credit, signaling that both banks, consumers and companies are more confident in getting involved in credit operations. On the other hand, the level of non-performing loans, interest rate and public indebtedness have negative effects. The international crisis of 2008 contracted credit in the country, which encouraged the slowdown of the Albanian economy. Like Albania, the Romania credit market underwent profound changes from the late 1990s and 2000s, with privatization and entry of foreign banks. According to Albulescu (2009), between 2003 and 2007, the share of total credit in the GDP amplified from $36 \%$ to $74 \%$. The author analyzed 
the factors that may have contributed both on the supply side and the demand for this strong credit expansion in the country. For this, he used a stochastic simulation econometric model (OLS Method) and monthly data for the period from August 2001 to May 2009. The conclusion is that the domestic conditions on the demand side, that is, GDP growth and decreasing interest rates until the middle of the year 2008, offered favorable conditions for the strong inflow of foreign resources to catapult the credit supply in the country. Nevertheless, with the reversal of the international supply of liquidity as of September 2008, Romania left the credit boom stage and plunged into the credit crunch phase, negatively affecting its economy.

Fritzer and Reiss (2008) analyzed the determinants of the stock of bank credit for individuals in Austria between 1981 and 2007. They noted that the period covered in the study involved a complete economic cycle, which allowed quantifying the impact of macroeconomic variables on the supply of credit. They developed their estimates using real-valued variables in a VECM/ECM (Error Correction Model) model. They demonstrated that, despite the economic expansion, Austria did not go through an asset bubble, especially real estate, in the period leading up to the 2008 crisis. The real GDP variation is the main explanatory factor for credit behavior, followed by the interest rate. Inflation over the 1990s shows a negative impact, but reaching a lower level from the early 2000s onwards, it has a positive impact. This is because the low inflation does not affect agent expectations, but small increases contribute to the expectation of a lower real interest rate. This is in agreement with Cotarelli et al. (2003), for whom, above a certain level, inflation has a negative effect on credit.

In the last two decades, several papers have sought to understand the determinants of credit in Brazil from different aspects and methodologies. Almeida e Divino (2016) used data from 75 banks operating in the country through a balanced panel to investigate the determinants of the credit supply of these banks in the period from 2001 to 2012. Surprisingly, they did not find macroeconomic variables with a direct impact about the credit dynamics. On the other hand, microeconomic factors inherent to each bank, such as the application of government securities, borrowing expenses, credit risk, in a negative way, and credit spreads, in a positive way, were statistically relevant to the credit supply.

These findings are partially conflicting with those of Fucidji and Prince (2009). By means of panel data estimated by MQO to analyze credit information from the 13 largest banks in Brazil in the period from 2001 to mid-2006, Fucidji and Prince (2009) also found evidence favorable to the importance of microeconomic factors, especially the profitability of government bonds. However, they 
found a GDP's positive impact on credit. Possibly, the difference between the study periods in each of the papers explains the distinct impact of GDP. Blum and Nakane estimated the determinants of bank credit using Generalized Method Moments (GMM) and data for 118 banks for the period from 2001 to mid-2004. The main objective of the authors was to verify the importance of capital regulation on the supply of capital. Their main conclusions were that the availability of capital positively affected the supply of credit, as well as GDP and the profitability of credit operations. The basic interest rate, however, had negative effects. Mendonça and Sachsida (2013) estimated the demand for credit in Brazil, separating demand from individuals and demand from companies from June 2000 to August 2012. Using Variable Instrumental (IV) and GMM methodologies, they pointed to a positive impact of GDP and negative impact of the cost of credit and the unemployment rate. When estimating an equation of determination of the credit supply, the authors found a negative impact of inflation and fundraising rate. Finally, Vasconcelos et al. (2004), when investigating the supply of bank credit through panel data for the 26 federative units of Brazil in the period from 1994 to 2002, found that absence of bank branch seemed to negatively affect the regional credit supply. In sum, either even when examining a single country, the different studies can point to a great diversity of the main determinants of credit, due to the analyzed period, or due of the specific objectives and methodologies applied.

From the set of papers examined, it is possible to extract that GDP growth is an important determinant of the behavior of bank credit. A growing GDP seems to increase banks' willingness to make credit offerings, given that with the growing economy, there is a greater ability for the borrower to pay. In the same way, consumers and companies feel more likely to raise their spending, including demanding credit. As well, the availability of domestic deposits or foreign funds seems to directly affect the availability of credit in the economy. In contrast, the more domestic credit is based on foreign liabilities, the greater the impact of eventual international crises on it tends to be. The interest rate has an effect not always predictable on credit. If its upsurge allows banks to increase their spread (difference in rates between credit operations and costs of funds) and the demand for credit has a low price-elasticity, the interest rate can have a positive impact on credit. However, in most cases, the interest rate seems to have a negative impact, either by raising the price of credit, which affects its demand, or by indicating to the banks themselves a likely deterioration of future borrowers' payment conditions. Besides, the impact of inflation seems to be uncertain, depending perhaps on the level of this variable. In a context in which the history of inflation is low and inflation expectations are anchored, a higher rate of inflation ends up reducing the real interest rate, which directly or indirectly, via a positive impact on the GDP, can increase the bank 
credit. On the other hand, if inflation is already at a high level or the economy has a recent history of uncontrolled inflation, the rise in inflation will negatively affect the expectations of economic agents, generating a negative impact on bank credit. Therefore, the relation of bank credit to some of its usual determinants seems to be rather an empirical question than a theoretical one.

In addition, it should be noted that the development of any debt-credit relationship, whether undertaken in the banking system or in the capital market, includes a broad set of economic and legal institutions capable of regulating and protecting the agents involved in the operation. Thus, the existence of a legal system guaranteeing private property rights and the terms of contractual agreements between economic agents is fundamental for the expansion of credit supply, especially in the capital markets. Similarly, as Berg and Levine (2004) have shown, there seems to be evidence that national legal systems based on Common Law are more conductive to the development of financial markets than those based on Civil Law. While all these issues are important, they are not discussed in detail in this article. This option stems from the understanding that the countries examined here have more similarities than differences in these aspects. For example, all these countries have a Civil Law legal system and have in the banking system the main source of credit available in the economy. Nevertheless, it is intended to examine them in more detail in future work.

Thus, our focus is on the main macroeconomic variables that are likely to affect bank credit, as presented in the next section.

\section{METHODOLOGY}

\section{II.1. Data}

To conduct this study, we searched quarterly data sets extracted from the IMF databases, including International Financial Statistics (IFS), World Economic Outlook (WEO) and Global Financial Stability Report (GFSR). In addition to these, other databases were still employed to complete the panel of data, such as the Federal Reserve Economic Data of St. Louis, the National Statistical Institute of Chile and the Central Bank of Uruguay. Thus, due to the availability of information, it resulted in an unbalanced panel.

The data used here comprise the period from the first quarter of 2000 to the fourth quarter of 2016 for the following South American countries: Argentina, 
Bolivia, Brazil, Chile, Colombia, Ecuador, Paraguay, Peru, Uruguay and Venezuela. Suriname, French Guiana and Guiana were excluded from the sample due to data limitations.

The variables used in this paper are:

- Private credit - claims on private/other sectors;

- Foreign liabilities - liabilities to non-residents/foreign liabilities;

- Domestic deposits - transferable/demand deposits; other/time and savings deposits;

- Inflation - consumer prices ${ }^{4}$;

- Real GDP - GDP, constant prices;

- Deposit rate - deposit rate;

- US Federal funds rate - Federal funds rate;

Therefore, all countries analyzed in this article were also in the work of Aghion et al. (2005), classified as countries of uncertain convergence with the reference country, the USA, due to the low level of financial development observed during the study period of that work, from 1960 to 1995 . In this context, it is relevant to verify if there is evidence of financial development in these economies from 2000 to 2016 as it may be an indicative of the ability of the South American countries to reduce the technological gap with developed countries in the coming decades.

\section{II.2. Empirical model}

Working with panel data allows the researcher to verify economic aspects that can 't be analyzed with cross section or time series data. Among the advantages of using such a methodology, we can highlight the fact that we have more information on the explanatory variables, lower degree of collinearity, greater number of degrees of freedom for the model and the heterogeneity of the cutting units to be studied.

The fixed effects model aims to control the effects of omitted variables that vary between individuals and yet remain constant over time. In other words, it is assumed that the intercept varies from one individual to another, but is constant over time; the other parameters are constant for all individuals, at all times. Con-

4 From 2000 to 2015, price inflation in Argentina was calculated from the Consumer Price Index (CPI) for Argentina available on the FRED Economic Data. For the year 2016, the CPI information is available in the FOCUS ECONOMICS database. 
sequently, all differences in behavior between individuals must be captured by the intercept.

Thus, in Greene (2018), the fixed effects model can be presented as:

$$
y_{i t}=x_{i t}{ }^{\prime} \beta_{i}+\alpha_{i}+\varepsilon_{i t}
$$

in which $\mathbf{x}$ represents a vector of explanatory variables, $\beta$ a vector of parameters, $\alpha_{i}$ the intercept that varies for each unit cross section, and $\varepsilon_{i t}$ the error term.

The fixed-effects model is the best option for modeling panel data when the intercept $\alpha_{i}$ is correlated with the explanatory variables. Moreover, since the intercept of the model is treated as a fixed parameter, it is also desirable to use fixed effects when observations are obtained from the entire population and inferences are sought for the individuals for whom data are available. On the other hand, in the model with random effects, it is considered that the individual is not correlated with the explanatory variables. That is, the model treats the intercepts as random variables, seeing that the individuals on whom data are available are random samples of a population. Thus, being $\alpha_{i}$ a random variable with mean value, $\alpha$, it is possible to express the intercept as:

$$
\alpha_{i}=\alpha+u_{i}
$$

in which $u_{i}$ is an error term that captures the heterogeneities of the model. The general model is given by:

$$
y_{i t}=x_{i t}^{\prime} \beta_{i}+\alpha+u_{i}+\varepsilon_{i t}
$$

To decide between the fixed effects model and the random effects model, the unobserved effect $\alpha_{i}$ must be analyzed. In situations where $\alpha_{i}$ is not correlated with the explanatory variables, the random effects model is the most indicated. Otherwise, if $\alpha_{i}$ is correlated with some explanatory variables, then the fixed effects model must be used. In the latter case, the random effects model generates inconsistent estimators (Wooldridge, 2002).

To verify if there is a correlation between $\alpha_{i}$ and the explanatory variables, the Hausman test was used. If the null hypothesis is not rejected, there is no evidence that $\alpha_{i}$ is correlated with the explanatory variables. Therefore, the random effects model should be used. On the other hand, if the null hypothesis is rejected, the fixed effects model must be used. 
Thus, the complete model initially proposed for this study is based on Guo and Stepanyan (2011):

$$
\begin{aligned}
& \text { Cred }_{i, t}=\beta_{0}+\beta_{1}\left(\text { Dep }_{i, t}+\text { Shdepo }_{i, t-4}\right)+ \\
& \beta_{2}\left(\text { non-residentLiabilityGrowth }_{i, t} \times \text { Shforeignlia }_{i, t-4}\right)+ \\
& \beta_{3} \pi_{i, t}+\beta_{4} \text { GDP }_{i, t-1}+\beta_{5} \text { DepositRate }_{i, t-1}+\beta_{6} \text { Fed }_{i, t}+\beta_{7} F E_{i}+\varepsilon_{i, t}
\end{aligned}
$$

where:

Cred $_{i, t}:$ Growth rate of credit to private sector, quarterly;

$\mathrm{Dep}_{i, t}$ : Growth rate of deposits, quarterly;

Shdepo $_{i, t-4}$ : Domestic deposits on total private sector credit four quarters ago; non-residentLiability Growth ${ }_{i, t}=$ Growth rate of liabilities to non-residents; Shforeignlia $_{i, t-4}$ : Liabilities to non-residents on total private sector credit four quarters ago;

$\pi_{i, t}:$ Inflation;

$G D P_{i, t-1}$ : Lagged GDP growth;

DepositRate $_{i, t-1}$ : Lagged deposit rate;

$\mathrm{Fed}_{i, t}$ : Change in US federal fund rate, obtained by the difference of four previous quarters;

According to most of the empirical literature on the subject, it is expected that bank credit be positively impacted by the volume of domestic funding, as well as foreign funding and economic growth. For interest rates, both domestic and U.S., the inflation is expected to negatively affect the growth rate of credit to private sector.

After estimating the data considering the fixed and random effects, we performed the residual autocorrelation and heteroscedasticity tests. In order to test the presence of serial autocorrelation, we used the test proposed by Wooldridge (2002) in which the null hypothesis is the absence of first-order autocorrelation, which is applied by Drukker (2003), who concludes that such a test has good properties for samples of considerable size. To verify if the variance of the model is constant, we adopted the modified Wald test for heteroscedasticity, whose null hypothesis is that the residuals are homoscedastic. If the presence of both problems is observed, we apply a third model in which the linear regression with panel corrected standard errors (PCSE) is estimated, assuming that the errors are heteroscedastic and correlated between the panels. 


\section{DESCRIPTIVE ANALYSIS}

Table 1 shows some descriptive statistics for level variables used in this study, as well as the correlation between them. It can be seen that the average volume of credit in the South American economies over the period 2000-2016 was approximately US\$133.83 billion, far below the maximum value found of just over US\$ 1.76 trillion. This value refers to Brazil in the second quarter of 2014. The same is true for deposits, which presented an average of US\$ 115.57 billion, compared to more than US\$1.33 trillion presented by Brazil, again in the second quarter of 2014. It is still possible to note that, on average, the ratio of credit operations/domestic deposits was approximately one to one. Therefore, it can be noted that, on average, the economies analyzed were not very leveraged, although, for example, there were cases such as Chile in the first quarter of 2008, which had a leverage ratio of three times.

The average annual economic growth of these South American countries over the period analyzed was equivalent to $3.1 \%$ in the quarter, although there are some extreme cases in Venezuela of $-26.65 \%$ and $36.06 \%$, respectively, in the first quarter of 2003 and 2004. Other countries, such as Argentina, also showed negative changes in GDP, reaching $-16.34 \%$ in the first quarter of 2002, in the face of the crisis that had arisen in that country. Brazil, on the other hand, presented an average quarterly economic growth of $2.57 \%$ over the period analyzed, with satisfactory results until mid-2014. From this year on, the country started to record negative rates, reaching values below $-5 \%$ in the fourth quarter of 2015 and in the first quarter of 2016, reflecting the instability generated by the political and economic crises experienced in the country.

Table 1. Descriptive statistics of variables, 2000-2016

\begin{tabular}{lcccccccc}
\hline & \multicolumn{9}{c}{ Variables } \\
\cline { 2 - 8 } Statistics & Cred & Dep & $\begin{array}{c}\text { Foreign } \\
\text { Liabilities }\end{array}$ & $\pi$ & GDP & $\begin{array}{c}\text { In- } \\
\text { terest } \\
\text { rate }\end{array}$ & $\begin{array}{c}\text { FED } \\
\text { fund } \\
\text { rate }\end{array}$ \\
\hline Average & 133.83 & 115.57 & 22.07 & 2.45 & 3.10 & 8.46 & 1.80 \\
\hline Median & 26.16 & 30.45 & 5.36 & 1.30 & 3.28 & 5.62 & 1.00 \\
Maximun & 1765.47 & 1331.70 & 287.73 & 50.33 & 36.06 & 75.70 & 6.50
\end{tabular}




\begin{tabular}{lccccccc} 
Minimum & 1.03 & 0.85 & 0.12 & -21.98 & -26.65 & 0.61 & 0.13 \\
\hline Stand. dev. & 313.15 & 258.44 & 53.33 & 5.60 & 4.56 & 8.08 & 2.07 \\
\hline Obs. & 624 & 624 & 624 & 666 & 651 & 679 & 680 \\
\hline
\end{tabular}

Correlation matrix

\begin{tabular}{|c|c|c|c|c|c|c|c|}
\hline \multirow[b]{2}{*}{ Variables } & \multicolumn{7}{|c|}{ Variables } \\
\hline & Cred & Dep & $\begin{array}{c}\text { Foreign } \\
\text { Liabilities }\end{array}$ & $\pi$ & $G D P$ & $\begin{array}{c}\text { In- } \\
\text { terest } \\
\text { rate }\end{array}$ & $\begin{array}{l}\text { FED } \\
\text { fund } \\
\text { rate }\end{array}$ \\
\hline Cred & 1 & & & & & & \\
\hline \multirow{2}{*}{ Dep } & 0.9833 & 1 & & & & & \\
\hline & $(00000)$ & & & & & & \\
\hline \multirow{2}{*}{$\begin{array}{l}\text { Foreing } \\
\text { Liabilities }\end{array}$} & 0.9627 & 0.9690 & 1 & & & & \\
\hline & $(0.0000)$ & $(0.0000)$ & & & & & \\
\hline \multirow{2}{*}{$\pi$} & -0.0084 & 0.0430 & -0.0443 & 1 & & & \\
\hline & $(0.8357)$ & $(0.2859)$ & $(0.2717)$ & & & & \\
\hline \multirow{2}{*}{$G D P$} & -0.1206 & -0.1156 & -0.0908 & -0.1176 & 1 & & \\
\hline & $(0.0036)$ & $(0.0052)$ & $(0.0283)$ & $(0.0035)$ & & & \\
\hline \multirow{2}{*}{ Interest rate } & 0.0748 & 0.1256 & 0.1309 & 0.2660 & -0.3873 & 1 & \\
\hline & $(0.0621)$ & $(0.0017)$ & $(0.0011)$ & $(0.0000)$ & $(0.0000)$ & & \\
\hline \multirow{2}{*}{$\begin{array}{l}\text { FED fund } \\
\text { rate }\end{array}$} & -0.1629 & -0.1380 & -0.1112 & -0.0337 & 0.0883 & 0.0982 & 1 \\
\hline & $(0.0000)$ & $(0.0005)$ & $(0.0054)$ & $(0.3850)$ & $(0.0270)$ & $(0.0105)$ & \\
\hline
\end{tabular}

Source: Research data. Note: Credit, Deposit and Foreign Liabilities in billions of dollars. Inflation, GDP and Interest Rate in percentage. Significance level between parentheses.

The average inflation of the South American countries for the period was $2.45 \%$. Venezuela stands out with the highest rates from the third quarter of 2015, 
when it presented an index of a little more than $30 \%$ and, from then on, followed an upward trend, reaching $50 \%$ in the second quarter of the following year, the highest value in the historical series. At the other extreme, with the lowest inflation rates, the highlight is also Venezuela. Here, the country recorded the highest deflation of the series in the second quarter of 2005 , with a rate of approximately $22 \%$.

Brazil had the highest external liabilities in all quarters analyzed. This probably had an impact on the availability of resources for financial institutions to make credit concessions. However, such a position is not necessarily comfortable because, depending on the composition of foreign capital, the country is more vulnerable to changes in the international scenario and to speculative attacks, generating pressure on the exchange rate, inflation and economic growth. Brazil had a foreign debt volume of US\$ 82.26 billion in the early 2000 s, with an upward trend thereafter, reaching the highest in the first quarter of 2013 at US\$287.72 billion, well above average value of US\$22.07 billion considering the other countries in the sample.

The correlation of the variables used in this study can be observed in the second part of Table 1. The variables domestic deposits, foreign liabilities, and deposit rate show a positive relation with the volume of credit operations to the private sector, since this relation is negative when analyzing the variables GDP, Fed fund rate and inflation. Nevertheless, it cannot be said that the first group of variables has a positive effect, as well as the second negative one, on bank credit, since this measure shows just how two variables relate to each other.

Figure 1 shows a graph for each analyzed country of South America, with the volume of credit operations and domestic deposits in billions of dollars on the primary axis and, on the secondary, the quarterly GDP growth rate, in percentage variations. Analyzing initially all the graphs in general, it can be verified that for the ten countries there is a long-term growth trend of both the volume of the credit operations and the volume of the bank deposits, since there is a coincident inflection point for all of them. Although in some cases this rupture is more sensitive than others are, this point corresponds to the world crisis, a period in which both variables interrupted their upward trajectories and have retraction of their values. The variables growth resumed some quarters later, a period that varies among the analyzed countries.

Regarding the quarterly GDP growth rate, it is generally possible to verify that in the South American countries there is no constant economic growth, since there is a great variation from one period to another in the same country, thus show- 
ing its cyclical character. In the case of Venezuela, this variation is very evident, with the country showing a retraction of more than $26 \%$ in the first quarter of 2003 and, a year later, growing by more than $36 \%$. In addition to that, it can be seen that, after the period of the economic crisis of 2008, all the South American countries presented high declines in economic growth rates compared with those that had been presenting until then. In fact, there was a slowdown when the crisis worsened at the end of 2008, but in general, countries were able to recover rapidly in the following quarters. However, from 2011 or 2012, this recovery began to fade and quarterly GDP rates fell again to levels below the pre-crisis period.

Argentina, Bolivia, Ecuador, Peru, Uruguay and Venezuela presented in the historical series total deposits higher than credit operations, indicating that these countries were not leveraging financially, since they granted a lower total credit compared with the received deposits. In the case of Chile, Colombia, and Paraguay, this analysis is inverted, since in almost all periods these countries granted a larger volume of credit than deposits, with Chile and Colombia reaching a ratio of more than twice in several moments of time.

In Brazil, it is possible to divide this analysis into two periods, up to the third quarter of 2007 and from the fourth quarter of the same year. In the first one, the volume of deposits was higher than the credit operations, reaching almost $60 \%$ higher in the third quarter of 2004. In the second period, this scenario has been reversed. The country becomes increasingly leveraged. At the end of 2013 and beginning of 2014, total loans were already more than $30 \%$ higher than the total deposits. This reflected a change in the behavior of financial agents, who began to encourage domestic lending although the volume of domestic deposits did not follow this growth, with credit was sustained by foreign liabilities. Symmetric analysis can be done for Uruguay, considering that, until the third quarter of 2003, credit concessions exceeded domestic deposits, a situation that since then is reversed, with credit now accounting for only $53 \%$ of deposits.

The crisis experienced by Argentina in the early 2000s had several disastrous consequences for the national and even international economy. Some of the impacts caused by it seen in Figure 1a. The crisis had its peak at the end of 2001 and early 2002. In November of 2001, Argentina experienced an episode of bank run. Economic agents increasingly suspicious about maintaining convertibility and parity of the peso against the dollar provoked a rush to the banks to withdraw resources. Consequently, on December 2, the government imposed a freeze on bank accounts for a period of 12 months and restricted withdrawals to a maximum 
Figure 1. Credit, deposits and GDP, Q1/2000 to Q4//2016

a) Argentina

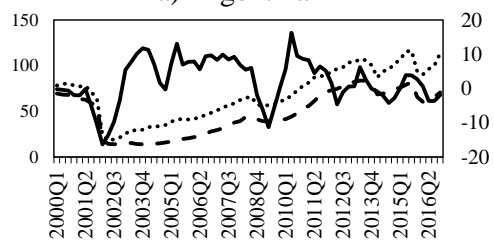

c) Brazil



e) Colombia

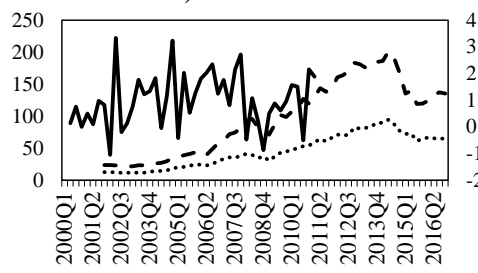

g) Paraguay



i) Uruguay

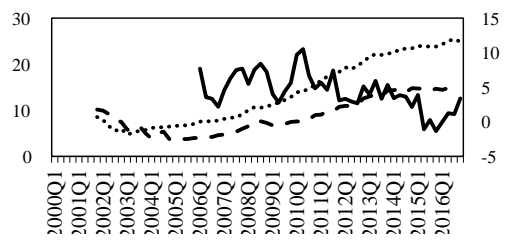

b) Bolivia

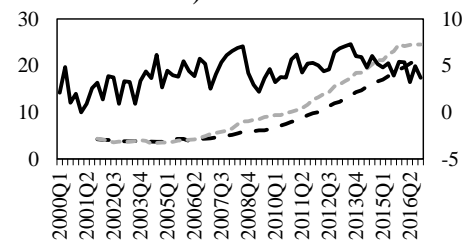

d) Chile



f) Ecuador



h) Peru

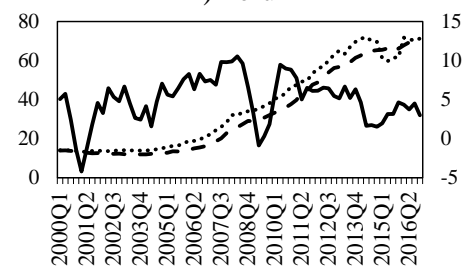

j) Venezuela

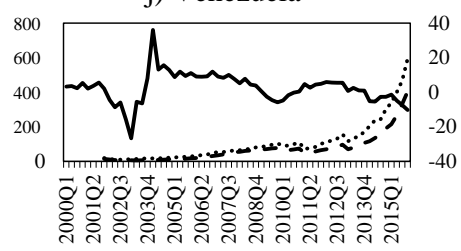
-- Credit Deposits GDP

Source: Research data. Note: credit and deposits in billions of dollars. 
of 250 pesos per week, an episode known as "corralito" and caused widespread popular revolt. As a result, the economic slowdown in the first quarter of 2002 reached $-16.34 \%$. Following this trend, the volume of credit operations and domestic deposits also dropped $68 \%$ and $63 \%$, respectively, in the same quarter of 2002 .

As discussed in the introduction of this paper, the ratio of bank credit to GDP is a proxy commonly used to measure the degree of a country's financial development. It also shows how important credit is to the economy. If there is more than proportional credit growth in relation to GDP, this indicator tends to increase. A growth of this relationship represents a greater confidence of the economic agents, both those who are responsible for offering credit and those who capture the resource. However, a broad expansion of credit-GDP ratio must be carefully analyzed. An imbalance can arise between credit growth and economic expansion, generating inflationary pressures on the prices of several assets. Moreover, increased indebtedness of households and businesses, which in the long term can generate a financial crisis with negative repercussions on the rest of the economy (Alessi \& Detken, 2018; Aikman et al., 2014; Schularick \& Taylor, 2012).

Figure 2 shows the evolution of the bank credit-GDP ratio for the ten countries, from the first quarter of 2000 to the last one in 2016 . Chile was the country that had the largest ratio throughout the period, from $63.70 \%$ in the fourth quarter of 2000 and reached $112.12 \%$, with a growth of approximately $76 \%$, being the only South American country where the volume of credit exceeded the domestic income. The other countries had an average rate of $30 \%$ of credit in relation to GDP throughout the analyzed period, slightly above the $25 \%$ of the value estimated as the minimum threshold for which credit has a positive effect for a country to be able to absorb the technological advances of developed countries, according to Aghion et al. (2005). On the other hand, with the exception of Chile, all the other countries are relatively distant from the $90 \%$ to $100 \%$ in which, according to Cecchetti and Kharroubi (2012), the credit-GDP ratio may turn negative.

Argentina showed a relative stability in the credit-GDP ratio from the first quarter of 2003 , when this ratio was $13.59 \%$, reaching close to $12.77 \%$ in the fourth quarter of 2016. However, at the beginning of the analyzed period a noticeable fall occurred. By mid-2000, this ratio was over $25 \%$, but down almost $50 \%$ the end of 2002. This fact can be explained as a result of the crisis faced by the country in 2001, which had as one of the main consequences the decline more than proportional in credit when compared to GDP. Even when the GDP showed positive 
growth rates, the credit-GDP ratio did not return pre-2001 levels, given the declines in credit to the private sector.

Credit-GDP ratio in Brazil presented a trajectory of growth in almost the entire period, achieving its maximum value in the last quarter of 2014, when it reached more than $70 \%$, which attracted attention from experts and policy makers. This because, although the expansion of access to credit by households is beneficial, given its positive effects for the expansion of consumption, investment and social welfare, it can bring some problems depending on the quality and modality of loans. In the specific case of Brazil, this expansion was influenced by the mortgage loan, which has low default rates. Furthermore, if compared to the international average of 130 percent or the OECD, 147 percent, Brazil does not have a high credit-GDP ratio, according to Bastos (2016).

Figure 2. Credit-GDP ratio, in percent, Q1/2000 to Q4/2016

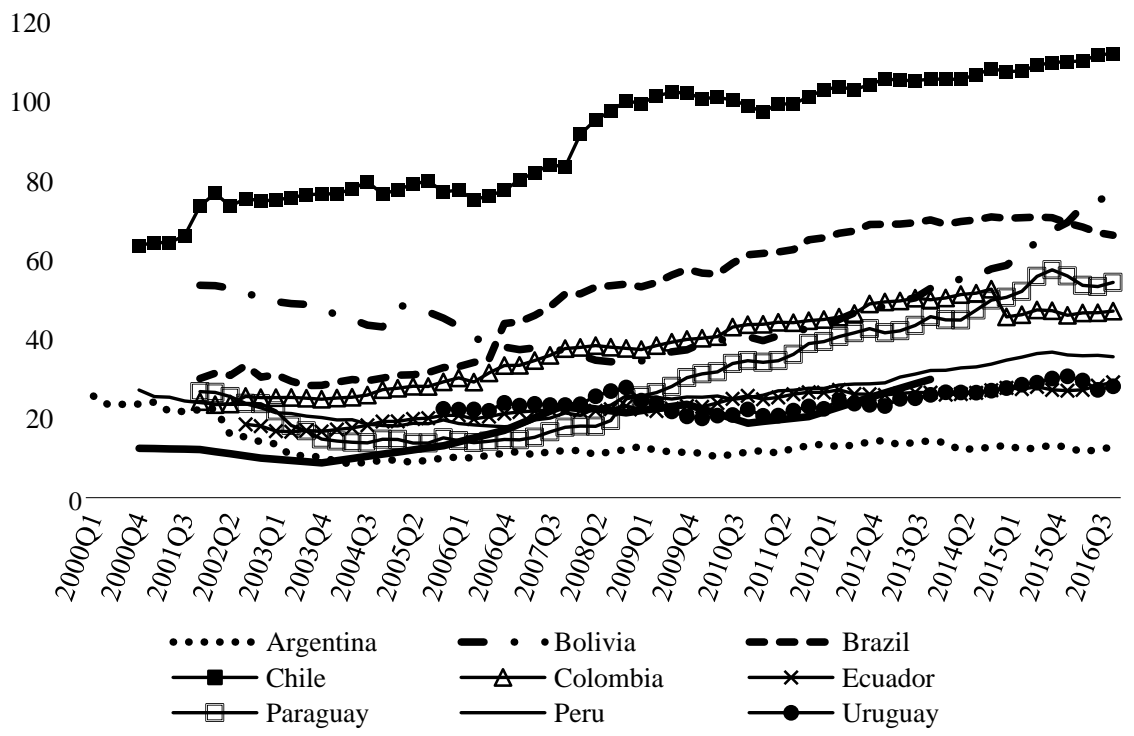

Source: Research data.

Considering the whole period, it is possible to observe that, for most of the countries, the credit-GDP ratio increased. If at the beginning of the series, with the exception of Chile and Bolivia, all countries had a relation close to the limit of $25 \%$ 
estimated by Aghion et al. (2005), in the end, only Argentina, Ecuador and Uruguay still remained below or close to such a limit.

\section{RESULTS AND DISCUSSIONS}

As shown in the methodology, estimates were made considering the fixed effect panel method and random effects, which are presented in specifications I and II, in Table 2. In addition to that, when necessary, in the presence of heteroscedasticity and autocorrelation, the specification III was made to correct such problems. The fixed effect technique seeks to capture the heterogeneity of the sample countries, or rather, the unobservable effects associated with historical aspects, technological standards, cultural and geographic differences, institutional quality of the nation, and other determinants of the credit supply which were not entered into the model and did not vary significantly over time.

Thus, Table 2 presents the results of the estimates considering all the countries analyzed in this study, in addition to those referring to the group composed of these same countries with the exception of Venezuela. The justification for making the same estimates excluding Venezuela consists of the fact that it presents the very characteristics that would probably be biasing the estimated results, since this country presented very discrepant values from the others when examining, for example, GDP growth and the evolution of bank credit and domestic deposits.

By excluding Venezuela from the group of countries and re-estimating tests, the results are similar to those previously exposed. All the coefficients presented the same signs, corroborating with what was already expected about the determinants: domestic deposits, economic growth and foreign liabilities positively affect the growth of credit. In turn, inflation and domestic and US interest rates influence negatively the credit variation. The main difference between the two estimates is that the fixed effects model was better adjusted, thus capturing the heterogeneities of the countries, a conclusion obtained after the Hausman test. Table 2. Results of the estimates considering all the countries of the sample and excluding Venezuela, from the first quarter of 2000 to the fourth quarter of 2016 


\begin{tabular}{|c|c|c|c|c|c|c|}
\hline \multirow[b]{2}{*}{ Variables } & \multicolumn{3}{|c|}{ All countries } & \multicolumn{3}{|c|}{ Without Venezuela } \\
\hline & (I) & (II) & (III) & (I) & (II) & (III) \\
\hline \multirow{2}{*}{$\begin{array}{l}\text { Domestic depos- } \\
\text { its x deposits/ } \\
\text { credit }\end{array}$} & $0.00466^{* * *}$ & $0.00467 * * *$ & $0.00377 * * *$ & $0.00505^{* * *}$ & $0.00504^{* * *}$ & $0.00459 * * *$ \\
\hline & $(0.000188)$ & $(0.000186)$ & $(0.000230)$ & $(0.000295)$ & $(0.000294)$ & $(0.000302)$ \\
\hline \multirow{2}{*}{ Inflation } & $-0.769 * * *$ & $-0.773 * * *$ & $-0.411 * * *$ & $-0.764 *$ & $-0.839^{* *}$ & $-0.825 * * *$ \\
\hline & $(0.144)$ & $(0.133)$ & $(0.132)$ & $(0.414)$ & $(0.412)$ & $(0.277)$ \\
\hline \multirow{2}{*}{$\begin{array}{l}\text { Lagged GDP } \\
\text { growth }\end{array}$} & $0.834 * * *$ & $0.823 * * *$ & 0.148 & $0.754 * * *$ & $0.711 * * *$ & 0.138 \\
\hline & $(0134)$ & $(0.133)$ & $(0.106)$ & $(0.158)$ & $(0.158)$ & $(0.106)$ \\
\hline \multirow{2}{*}{$\begin{array}{l}\text { Lagged interest } \\
\text { rate }\end{array}$} & $-0.666^{* * *}$ & $-0.661^{* * *}$ & $-0.458 * * *$ & $-0.623 * * *$ & $-0.617^{* * *}$ & $-0.430 * * *$ \\
\hline & $(0.0888)$ & $(0.0876)$ & $(0.106)$ & $(0.0873)$ & $(0.0868)$ & $(0.109)$ \\
\hline \multirow{2}{*}{$\begin{array}{l}\text { Foreign liabili- } \\
\text { ties x liabilities/ } \\
\text { credit }\end{array}$} & $0.00117 * * *$ & $0.00119 * * *$ & $0.000460 *$ & $0.00112 * * *$ & $0.00117 * * *$ & 0.000221 \\
\hline & $(0.000415)$ & $(0.000413)$ & $(0.000262)$ & $(0.000426)$ & $(0.000427)$ & $(0.000238)$ \\
\hline \multirow{2}{*}{$\begin{array}{l}\text { Change in US } \\
\text { federal fund rate }\end{array}$} & -0.375 & -0.365 & -0.447 & -0.181 & -0.153 & -0.709 \\
\hline & $(0.424)$ & $(0.422)$ & $(0.590)$ & $(0.427)$ & $(0.431)$ & $(0.587)$ \\
\hline \multirow{2}{*}{ Constant } & $7.238 * * *$ & $7.756^{* * *}$ & $8.804 * * *$ & $6.321 * * *$ & $7.019 * * *$ & $7.417 * * *$ \\
\hline & $(1.155)$ & $(2.705)$ & $(1.672)$ & $(1.251)$ & $(1.895)$ & (1.884) \\
\hline Observations & 557 & 557 & 557 & 504 & 504 & 504 \\
\hline $\begin{array}{l}\text { Number of } \\
\text { countries }\end{array}$ & 10 & 10 & 10 & 9 & 9 & 9 \\
\hline $\mathrm{R}^{2}$ & 0.6700 & & 0.4744 & 0.5992 & & 0.4304 \\
\hline $\begin{array}{l}\text { Heteroskedas- } \\
\text { ticity }\end{array}$ & $1986.10^{* * *}$ & & & $1493.75 * * *$ & & \\
\hline Autocorrelation & $145.966^{* * *}$ & & & $115.633 * * *$ & & \\
\hline Hausman test & & 1.04 & & $45.56^{* * * *}$ & & \\
\hline
\end{tabular}

Source: Authors' estimates. Note: standard error between parentheses. ${ }^{* * *}$ Level of significance of $1 \%$; ** Level of significance of $5 \%$; * Level of significance of $10 \%$.

In addition to the differences between countries in relation to their characteristics captured in fixed-effects estimates, their financial systems are not homogeneous. Table 3 presents the estimates by segmenting the countries into two groups according to their level of financial development. For this division, we use the Financial Development Index (FDI) calculated by the International Monetary Fund (IMF). For each country, the average FDI was calculated in the period from 2000 to 2016 and compared to the average Western Hemisphere FDI in the same period (value 0.29). Countries in 
the sample that were above this value were classified as "more developed financially", plus Peru, with an average FDI of 0.28 and 0.08 points above the country of the least developed group with the highest score. Moreover, Argentina (0.33), Brazil (0.53), Chile (0.48), Colombia (0.35) and Peru (0.28) are part of the group of countries with more developed financial systems, while Bolivia (0.18), Ecuador (0.17), Paraguay (0.11), Uruguay (0.19) and Venezuela (0.20) are part of the less developed group.

Table 3. Results of the estimates considering two distinct groups of countries, from the first quarter of 2000 to the fourth quarter of 2016

\begin{tabular}{|c|c|c|c|c|c|c|}
\hline \multirow[b]{2}{*}{ Variables } & \multicolumn{3}{|c|}{ More developed financial systems } & \multicolumn{3}{|c|}{ Less developed financial systems } \\
\hline & (I) & (II) & (III) & (I) & (II) & (III) \\
\hline \multirow{2}{*}{$\begin{array}{l}\text { Domestic deposits } \mathrm{x} \\
\text { deposits/credit }\end{array}$} & $0.00447 * * *$ & $0.00481 * * *$ & $0.00456 * * *$ & $0.00456 * * *$ & $0.00472 * * *$ & $0.00348 * * *$ \\
\hline & $(-0.000408)$ & $(-0.000431)$ & $(-0.000367)$ & $(0.000217)$ & $(0.000199)$ & $(0.000279)$ \\
\hline \multirow{2}{*}{ Inflation } & $-1.057^{*}$ & $-1.455^{* * *}$ & $-1.255^{* * *}$ & $-0.790 * * *$ & $-0.705^{* * *}$ & $-0.320^{* *}$ \\
\hline & $(-0.538)$ & $(-0.54)$ & $(-0.418)$ & $(0.150)$ & $(0.150)$ & $(0.142)$ \\
\hline \multirow{2}{*}{ Lagged GDP growth } & $1.148^{* * * *}$ & $0.495^{*}$ & 0.391 & $0.645^{* * *}$ & $0.753 * * *$ & 0.109 \\
\hline & $(-0.267)$ & $(-0.273)$ & $(-0.24)$ & $(0.156)$ & $(0.156)$ & (0.119) \\
\hline \multirow{2}{*}{ Lagged interest rate } & $-0.724^{* * *}$ & $-0.660 * * *$ & $-0.580^{* * *}$ & $-0.662 * * *$ & $-0.575^{* * *}$ & $-0.455^{* * *}$ \\
\hline & $(-0.166)$ & $(-0.151)$ & $(-0.15)$ & $(0.110)$ & $(0.0999)$ & $(0.149)$ \\
\hline \multirow{2}{*}{$\begin{array}{l}\text { Foreign liabilities x } \\
\text { liabilities/credit }\end{array}$} & $0.00153 * * *$ & $0.00147 * * *$ & 0.000296 & -0.000227 & 0.000630 & -0.000237 \\
\hline & $(-0.00049)$ & $(-0.000516)$ & $(-0.000242)$ & $(0.000981)$ & $(0.000976)$ & $(0.00114)$ \\
\hline \multirow{2}{*}{$\begin{array}{l}\text { Change in US federal } \\
\text { fund rate }\end{array}$} & 0.447 & 0.889 & -0.498 & $-1.700 * * *$ & $-1.532 * *$ & -0.802 \\
\hline & $(-0.594)$ & $(-0.655)$ & $(-0.801)$ & $(0.637)$ & $(0.650)$ & $(0.836)$ \\
\hline \multirow{2}{*}{ Constant } & $9.652 * * *$ & $10.99 * * *$ & $10.20 * * *$ & $6.516^{* * *}$ & $4.579 * * *$ & $8.675^{* * *}$ \\
\hline & $(-2.123)$ & $(-1.776)$ & $(-2.949)$ & $(1.560)$ & $(1.335)$ & $(1.915)$ \\
\hline Observations & 280 & 280 & 280 & 277 & 277 & 277 \\
\hline Number of countries & 5 & 5 & 5 & 5 & 5 & 5 \\
\hline $\mathrm{R}^{2}$ & 0.6344 & & 0.4830 & 0.7160 & & 0.5360 \\
\hline Heteroskedasticity & $66.49^{* * *}$ & & & $720.27 * * *$ & & \\
\hline Autocorrelation & $79.471 * * *$ & & & $39.839 * * *$ & & \\
\hline Hausman test & $158.37 * * *$ & & & $18.77 * * *$ & & \\
\hline
\end{tabular}

Source: Authors' estimates. Note: Standard error between parentheses. $* * *$ Level of significance of $1 \%$;* Level of significance of $5 \%$; * Level of significance of $10 \%$. 
For countries with more developed financial systems, the fixed and random effects panel estimates presented the coefficients as significant and expected, with the exception of the FED fund rate. The Hausman test has shown that the fixed effects model was better adjusted when compared to the random effects model, although the model showed heteroscedasticity and autocorrelation in the residuals. In this way, we estimated the third method, which corrects both problems, in which all the parameters obtained presented the expected signs, even the US interest rate, although the coefficient of determination obtained has reduced from $63.44 \%$ to $48.30 \%$.

In the group of countries with a less developed financial system, the results are satisfactory since the estimated coefficients were significant and with the expected signs, with the exception of the foreign liabilities in method I and III. In both models I and II, the highlight is the US interest rate which, in addition to presenting a negative sign, was statistically significant at $1 \%$ and $5 \%$, respectively. This suggests that for the group of countries evaluated US monetary policy has a representative impact, and a more restrictive posture has the effect of reducing credit in the countries under review.

However, again, the tests pointed to the presence of heteroscedasticity and autocorrelation, and it is also necessary to carry out the estimations by the third method to correct them. Thus, as in the estimates of the countries with the most developed financial system, $\mathrm{R}^{2}$ presented a reduction from $71.60 \%$ to $53.60 \%$, indicating that this method, despite correcting statistical problems, is less efficient.

The financial crisis of 2008 has had serious consequences for all countries, from reducing economic growth and employment to insecurity about the ability of the financial system to manage the risks inherent in the market. Table 4 shows the results of the estimates considering two different periods: from the first quarter of 2000 to the fourth quarter of 2008 and from the first quarter of 2009 to the last quarter of 2016.

For the period before the financial crisis, it is observed that for both the fixed effects model and the random effects model, the signs of the estimated coefficients presented the expected signs as well as were statistically significant, except for the Fed fund rate, which did not present statistical significance. Again, the estimation of the third model was necessary, as the presence of heteroscedasticity and autocorrelation were verified in the initial model. In this way, the signs obtained in the new estimation corroborate the others, that is, domestic deposits, economic growth and liabilities to non-residents that positively impact the growth rate of credit and the other determinants, in a negative way. 
In the post-crisis period, the results are similar to those of the pre-crisis. However, it can be seen that the variable inflation stopped being an explanatory factor of the volume of credit. In part, this fact explained by the economic conjuncture of this period, in which inflation ceases to be the variable that captures the uncertainty and insecurity of the market, for in the post-crisis years their variance become lower. In addition, it is noted that GDP growth had a more significant impact on the pre-crisis period and the deposit rate in the post-crisis period on the volume of credit. Moreover, it is possible to verify that such variables considered as determinants are able to explain the changes in credit more efficiently in the post-crisis time, given that the $\mathrm{R}^{2}$ for this period is $69.71 \%$, compared to $31.26 \%$ of the pre-crisis.

Table 4. Results of the estimates considering all countries of the sample, precrisis period and international post-crisis period

\begin{tabular}{|c|c|c|c|c|c|c|}
\hline \multirow[b]{2}{*}{ Variables } & \multicolumn{3}{|c|}{$\mathrm{Q} 1 / 2000-\mathrm{Q} 4 / 2008$} & \multicolumn{3}{|c|}{$\mathrm{Q} 1 / 2009-\mathrm{Q} 4 / 2016$} \\
\hline & (I) & (II) & (III) & (I) & (II) & (III) \\
\hline \multirow{2}{*}{$\begin{array}{l}\text { Domestic deposits x } \\
\text { deposits/credit }\end{array}$} & $0.00414 * * *$ & $0.00436^{* * *}$ & $0.00325 * * *$ & $0.00453 * * *$ & $0.00455^{* * *} *$ & $0.00413 * * *$ \\
\hline & $(-0.000403)$ & $(-0.000385)$ & $(-0.000406)$ & $(0.000175)$ & $(0.000178)$ & $(0.000228)$ \\
\hline \multirow{2}{*}{ Inflation } & $-0.894 * * *$ & $-0.907 * * *$ & $-0.424 * *$ & -0.101 & -0.169 & -0.209 \\
\hline & $(-0.199)$ & $(-0.202)$ & $(-0.174)$ & $(0.215)$ & $(0.216)$ & $(0.254)$ \\
\hline \multirow{2}{*}{ Lagged GDP growth } & $0.966 * * *$ & $0.878 * * *$ & 0.0885 & $0.605 * * *$ & $0.637 * * *$ & $0.286 * * *$ \\
\hline & $(-0.237)$ & $(-0.241)$ & $(-0.196)$ & $(0.126)$ & $(0.127)$ & $(0.0885)$ \\
\hline \multirow{2}{*}{ Lagged interest rate } & $-0.690 * * *$ & $-0.653 * * *$ & $-0.448 * * *$ & $-1.578 * * *$ & $-1.012^{* * *}$ & $-0.786 * * *$ \\
\hline & $(-0.121)$ & $(-0.118)$ & $(-0.148)$ & $(0.283)$ & $(0.191)$ & $(0.228)$ \\
\hline \multirow{2}{*}{$\begin{array}{l}\text { Foreign liabilities x } \\
\text { liabilities/credit }\end{array}$} & $0.00107 *$ & $0.00112 *$ & $0.000572 * *$ & $0.00132 *$ & $0.00136^{*}$ & 0.000433 \\
\hline & $(-0.000571)$ & $(-0.000574)$ & $(-0.00029)$ & $(0.000766)$ & $(0.000775)$ & $(0.000958)$ \\
\hline \multirow{2}{*}{$\begin{array}{l}\text { Change in US federal } \\
\text { fund rate }\end{array}$} & -0.6 & -0.51 & -0.226 & -0.231 & -0.111 & 0.546 \\
\hline & $(-0.555)$ & $(-0.57)$ & $(-0.789)$ & $(0.807)$ & $(0.823)$ & $(0.982)$ \\
\hline \multirow{2}{*}{ Constant } & $8.939 * * *$ & $8.549 * * *$ & $10.47 * * *$ & $12.23 * * *$ & $9.041 * * *$ & $9.399 * * *$ \\
\hline & $(-2.176)$ & $(-2.632)$ & $(-2.973)$ & $(2.026)$ & $(1.677)$ & $(1.699)$ \\
\hline Observations & 267 & 267 & 267 & 290 & 290 & 290 \\
\hline Number of countries & 10 & 10 & 10 & 10 & 10 & 10 \\
\hline $\mathrm{R}^{2}$ & 0.6192 & & 0.3126 & 0.8125 & & 0.6971 \\
\hline Heteroskedasticity & $1833.37 * * *$ & & & $379.02 * * *$ & & \\
\hline Autocorrelation & $92.606^{* * *}$ & & & $39.858 * * *$ & & \\
\hline Hausman test & & 6.08 & & $17.40^{* * *}$ & & \\
\hline
\end{tabular}

Source: Authors' estimates. Note: Standard error between parentheses. $* * *$ Level of significance of $1 \%$; ** Level of significance of $5 \%$; * Level of significance of $10 \%$. 
The positive impact on bank credit caused by domestic deposits, foreign liabilities and economic growth, as well as the negative influence of domestic and US interest rates and inflation, are in agreement with several empirical papers that also studied the determinants of the bank credit of the most different forms, like Assefa (2014), Shijaku and Kalluci (2013), Mendonça and Sachsida (2013), Albulescu (2009), Fucidji and Prince (2009), Fritzer and Reiss (2008). Specifically for the inflation variable, our estimates for the whole time indicate that it has a negative impact on bank lending, contrary to what Guo and Stepanyan (2011) found for a sample of emerging economies. As already explained, it seems that the relationship between these two variables (bank credit and inflation) is sensitive to inflationary expectations and inflation expectations. In fact, even in our study, the relationship seems to have weakened in period from 2009 to 2016, when inflation lost statistical significance, such as that observed by Imram and Nishat (2012) for Pakistan after 2008. In summary, we found evidence that macroeconomic variables affect bank credit in the South American economies, contrary to the finding of Almeida and Divino (2016) specifically for Brasil.

Finally, we make decomposition estimations to verify the contribution of each determinant to bank credit variation. For this, fixed effects estimates were considered in order to capture differences between countries, calculating the specific credit decomposition for each of the samples. As shown in Figure 3, this calculation was performed for the entire interval included in this study, as well as for the two time: the pre-2008 world crisis and the post-crisis one. Our objective is to analyze if there were significant changes between the periods on the composition of the credit with regard to the determinants considered.

Initially, analyzing the full period, it is clear that, in addition to the specific effects of the different countries, the growth of domestic deposits and real GDP growth are the main components of credit expansion, so that, in all countries, deposits contribute more expressively, being $25 \%$ the fraction of credit attributed to deposits in South America. On the other hand, the domestic deposit rate and inflation contribute negatively to the growth of bank credit, and the share of interest rate is notably higher than that attributed to the price level, reaching $-19 \%$ and $-17 \%$ in Argentina and in Brazil, respectively.

GDP growth stopped being so important in the composition of credit variation, since in all countries, including South America as a whole, this determinant showed a drop in its share of credit, which dropped from almost $9 \%$ in the pre-crisis period and became little more than $4 \%$ in the post-crisis period. 
Figure 3. Decomposition of bank credit growth in South America, in percentage

a) Decomposition of bank credit, Q1/2000 - Q4/2016

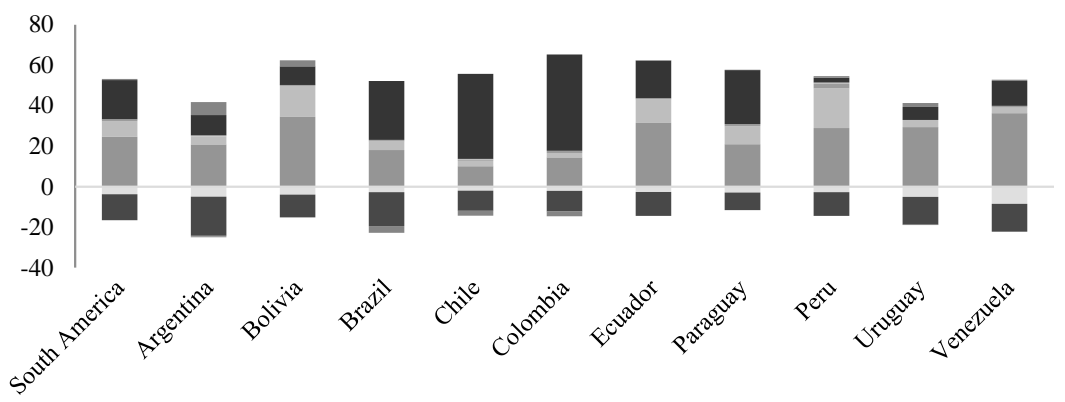

b) Decomposition of bank credit, Q1/2000 - Q4/2008

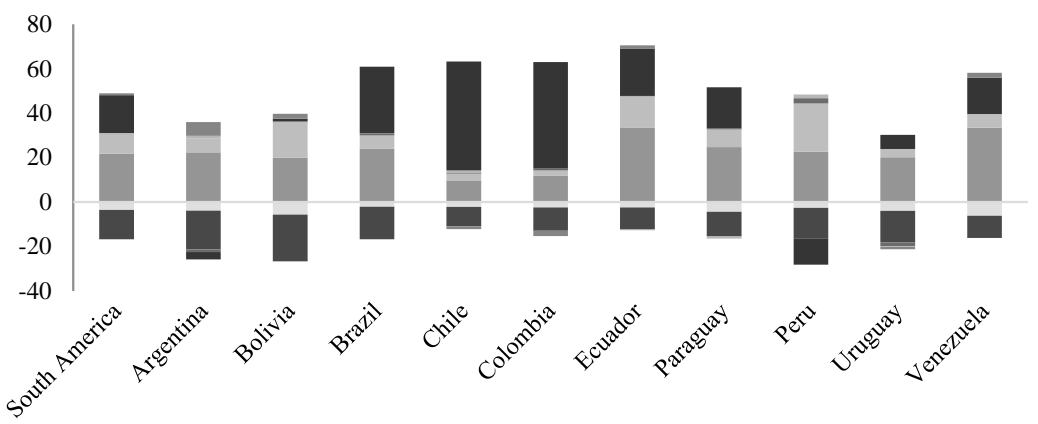

c) Decomposition of bank credit, Q1/2009 - Q4/2016



Source: Authors' estimates. 
Comparing the decomposition of credit growth between the pre-crisis and post-crisis periods, it can be seen that in both cases the main determinants that contribute positively remain domestic deposits and economic growth, despite the drop analyzed previously, and, in turn, inflation and interest rate, in a negative way. However, in the post-crisis period, with the exception of Bolivia, the interest rate began to play a much more significant role in the composition of credit, so that, in South America until the crisis, such a determinant contributed in $-13 \%$, value which increased to approximately $-23 \%$ in the post-crisis period. Inflation, which until 2008 was an important component of credit operations, ceased to exist, since its contribution in the credit variation did not exceed $-1 \%$ in all the countries analyzed, with the exception of Venezuela (- $1.23 \%)$.

It should also be noted the impact that the specific effect of each country had after the 2008 Crisis. With the exception of Chile, in all countries unobservable heterogeneities began to play a prominent role in the composition of credit growth. It happened because each country has its own institutional structure and adopted different measures and economic policies to try to recover from the crisis, which affected in different ways the volume of credit.

\section{ROBUSTNESS CHECK}

To perform the robustness analysis, we estimate a dynamic panel data model, considering as an endogenous variable, in addition to the lags dependent variable, the growth of the lagged GDP. The literature on the relationship between bank credit and GDP is quite controversial. Several papers, such as Levine (1997), Rajan and Zingales (1998), Levine et al. (2000), Beck et al. (2008), try to identify the direction of causality between these variables, finding that credit, used as a proxy for the development of the financial system, would be able to positively impact economic growth. This relationship derives from five channels. A more developed financial system would be able to produce ex ante information on possible investments and capital allocations, monitor investments after providing funding, promote trading, diversification and risk management, mobilize and accumulate savings, and facilitate the exchange of goods and services.

Thus, in the face of this relationship indicating a possible endogeneity in the models and seeking to perform the robustness analysis, we will estimate a dynamic panel data model, considering as endogenous variables the lags dependent variable and the growth of the lagged GDP. Therefore, according to Greene (2018), this model can be described as: 


$$
y_{i t}=\alpha_{i}+\gamma y_{i t-1}+x_{i t}^{\prime} \beta_{i}+\varepsilon_{i t}
$$

in which the variables contained in vector $\mathrm{x}$ are those defined in equation (4). We use the Generalized Method of Moments (GMM) system estimator, proposed by Arellano and Bover (1995) and Blundell and Bond (1998), which produces robust estimates in the presence of endogeneity, considering instruments as lagged values of the endogenous variables. According to Table 5, we estimate five regressions, for all countries (I), for those with the highest (II) and lowest (III) financial development, for the period (IV) up to the financial crisis of 2008 and after $(\mathrm{V})$ that period.

We apply the Hansen test to evaluate the validity of the set of instruments implemented in each estimate, assuming that not rejecting the null hypothesis is indicative that the instruments are valid. Thus, analyzing the p-value of the Hansen test of the five models presented in Table 5, in all it can be concluded that the instruments used have proved valid. Furthermore, when we look the autocorrelation tests, it is possible to imply that, in all the dynamic specifications presented, it was not possible to reject the null hypothesis of absence of autocorrelation in two periods, suggesting that in these models there is no presence of autocorrelation.

It can be seen that the lagged dependent variable is statistically significant in all specifications, which justifies the introduction of dynamic econometric models as an auxiliary tool for analysis of this empirical study. In general, the signs of the coefficients of the dynamic specifications are similar to those of fixed and random effects presented above. However, as expected, the level of the estimated coefficients are smaller than those estimated in the static model, since in the dynamic model, the history of the dependent variable is captured by the lagged dependent variable and the other variables capture the contemporary impact.

The model that considers all countries in the estimation presents results similar to those in the static estimates, with the exception of the Fed fund rate that showed a positive sign here, although it was not statistically significant. Thus, for the countries of South America, it can be concluded that the lagged credit, domestic deposits, economic growth and foreign liabilities positively influence the growth of bank credit, while inflation and the deposit rate affect it negatively. 
Table 5. Results of dynamic estimates

\begin{tabular}{|c|c|c|c|c|c|}
\hline Variables & (I) & (II) & (III) & (IV) & (V) \\
\hline Cred $_{t-1}$ & $\begin{array}{c}0.6381 * * * \\
(0.3888)\end{array}$ & $\begin{array}{c}0.6331 * * * \\
(0.0513)\end{array}$ & $\begin{array}{c}0.6362 * * * \\
(0.0634)\end{array}$ & $\begin{array}{c}0.7244 * * * \\
(0.0228)\end{array}$ & $\begin{array}{c}0.4523 * * * \\
(0.0779)\end{array}$ \\
\hline \multirow{2}{*}{$\begin{array}{l}\text { Domestic deposits x } \\
\text { deposits/credit }\end{array}$} & $0.0023 * * *$ & $0.0027 * * *$ & $0.0021 * * *$ & $0.0017 * * *$ & $0.0031 * * *$ \\
\hline & $(0.00017)$ & $(0.0007)$ & $(0.0002)$ & $(0.0003)$ & $(0.0003)$ \\
\hline \multirow{2}{*}{ Inflation } & $-0.3972 * * *$ & $-1.1795 * * *$ & $-0.2208 * * *$ & -0.2052 & $-0.6568 *$ \\
\hline & $(0.1292)$ & $(0.3486)$ & $(0.0319)$ & $(0.1308)$ & $(0.3661)$ \\
\hline \multirow{2}{*}{ Lagged GDP growth } & 0.1278 & -0.2350 & $0.2847 * *$ & 0.1100 & $0.2989 * * *$ \\
\hline & $(0.1312)$ & $(0.2078)$ & $(0.1240)$ & $(0.1673)$ & $(0.1085)$ \\
\hline \multirow{2}{*}{ Lagged interest rate } & $-0.2219 * * *$ & $-0.2483 * *$ & $-0.2557 * * *$ & $-0.1597 * * *$ & -0.2902 \\
\hline & $(0.0627)$ & $(0.1096)$ & $(0.0686)$ & $(0.0445)$ & $(0.2154)$ \\
\hline \multirow{2}{*}{$\begin{array}{l}\text { Foreign liabilities x } \\
\text { liabilities/credit }\end{array}$} & 0.0006 & 0.0006 & -0.001 & 0.0006 & 0.0002 \\
\hline & $(0.0004)$ & $(0.0006)$ & $(0.0008)$ & $(0.0005)$ & $(0.0006)$ \\
\hline \multirow{2}{*}{$\begin{array}{l}\text { Change in US federal } \\
\text { fund rate }\end{array}$} & 0.6195 & 0.9171 & 0.0832 & $0.7463 *$ & -0.2670 \\
\hline & $(0.3932)$ & $(0.7635)$ & $(0.3885)$ & $(0.4497)$ & $(1.0235)$ \\
\hline \multirow{2}{*}{ Constant } & $2.2679 * *$ & $4.7688 * * *$ & 1.0527 & $1.9894 *$ & $3.4067 * *$ \\
\hline & $(1.0501)$ & $(1.3050)$ & $(0.7116)$ & $(1.1885)$ & $(1.3721)$ \\
\hline Observations & 546 & 275 & 271 & 256 & 280 \\
\hline Number of countries & 10 & 5 & 5 & 10 & 10 \\
\hline $\mathrm{AR}(1)-p$ value & 0.011 & 0.048 & 0.074 & 0.013 & 0.018 \\
\hline $\mathrm{AR}(2)-p$ value & 0.250 & 0.394 & 0.368 & 0.083 & 0.575 \\
\hline Hansen Overid. $-p$ value & 1.000 & 1.000 & 1.000 & 1.000 & 1.000 \\
\hline \multicolumn{6}{|c|}{ Difference-in- Hansen tests of exogeneity of instrument subsets (chi ${ }^{2}$ test for GMM instruments): } \\
\hline Hansen $-p$ value & 0.267 & 1.000 & 1.000 & 0.092 & 0.994 \\
\hline Difference $-p$ value & 1.000 & 1.000 & 1.000 & 1.000 & 1.000 \\
\hline
\end{tabular}

Source: Authors' estimates. Note: Standard error between parentheses. *** Level of significance of $1 \%$; ** Level of significance of 5\%; * Level of significance of $10 \%$. AR(1) and AR(2) are the ArellanoBond test for autoregressive process of order 1 and 2 in the first differences, respectively. "Hansen Overid." are the Hansen tests of over-identification restrictions. 


\section{CONCLUSION}

The study of the determinants of bank credit operations is relevant since the financial system is considered to have a direct influence on economic growth. Thus, analyzing the credit and verifying its main determinants and the respective impacts was the main objective of this study. For this purpose, data series were used for the countries of South America from 2000 to 2016.

Initially, the main determinants of credit were found in the pertinent literature, and the following variables were suggested: domestic deposits, foreign liabilities, GDP, deposit rate and the Fed fund rate. Domestic deposits and liabilities to non-residents had the highest correlations with credit operations, which were more than $90 \%$ in both cases.

The results of the estimates indicate that domestic deposits, economic growth and foreign liabilities positively influence the volume of credit operations. In turn, inflation rate, domestic and USA interest rates negatively impact loans. Thus, there is evidence that a more restrictive monetary policy, both by the US and by local governments, reduces the supply of credit in the South American countries.

In addition, it is important to note that most countries in the region have been able to expand the supply of credit in their economies, avoiding falling below the $25 \%$ credit-GDP ratio threshold. This limit, as pointed out by Aghion et al. (2005), characterizes a situation of financial constraint that hinders or even impedes the absorption by domestic agents of foreign technologies. On the other hand, with the exception of Chile, South American economies are still far from the level of $90 \%$ to $100 \%$ of this it proportion, where, according to Cecchetti and Kharroubi (2012), begins a negative association between the two variables.

Finally, the presented estimates suggest the positive importance of domestic deposits and liabilities to non-residents to the supply of credit. Although part of these deposits is demandable in the short term, that is, demand deposits, a relevant part consists of different forms of time deposits, reflecting part of the national savings directed to the banking system. Foreign liabilities can be considered as a proxy for the foreign savings received by the South American economies. Thus, the challenge of the economies of the region is to constitute policies that induce the formation of domestic savings and the attraction of external savings, as well as to structure a banking system capable of allocating these resources efficiently. Future articles should be aimed to examine whether the banking systems of the South American countries are structured in this direction. 


\section{REFERENCES}

Aghion, P., Howitt, P., \& Mayer-Foulkes, D. (2005). The effect of financial development on convergence: Theory and evidence. Quarterly Journal of Economics, 120 (1), 173-222.

Aikman, D., Haldane, A. G., \& Nelson, B.D. (2014). Curbing the credit cycle. Economic Journal, 125 (585), 1072-1109.

Aizenman, J. (2005). Financial Liberalizations in Latin America in the 1990s: A Reassessment. The World Economy, 28 (7), 959-983.

Albulescu, C. T. (2009). Forecasting credit growth rate in Romania: from credit boom to credit crunch? Munich Personal RePEc Archive, MPRA Paper No. 16740.

Alessi, L., \& Detken, C. (2018). Identifying excessive credit growth and leverage. Journal of Financial Stability, 35, 215-225.

Almeida, F. D., \& Divino, J. A. (2016). Determinantes do Crédito Bancário no Brasil: Uma Análise de Fatores Micro e Macroeconômicos, XLIV Encontro Nacional de Economia da ANPEC. Associação Nacional dos Centros de Pós-Graduação em Economia, Foz do Iguaçu.

Arellano, M. \& Bover, O. (1995). Another Look at the Instrumental Variable Estimation of Error-Components Models. Journal of econometrics, 68 (1), 29-51.

Assefa, M. (2014). Determinants of Growth in Bank Credit to the Private Sector in Ethiopia: A Supply Side Approach. Research Journal of Finance and Accounting, 5 (17), 90-103.

Bagehot, W. (1873). Lombard Street. London: Richard D. Irwin. (1962 Edition).

Bastos, E. K. X. (2016). Carta de Conjuntura. Crédito. v. 33, $4^{\circ}$ tri.

Beck, T.; Demirguc-Kunt, A.; Laeven, L. \& Levine, R. (2008) Finance, Firm Size, and Growth. Journal of Money, Credit and Banking, 40 (7), 1379-1405.

Beck, T. \& Levine, R. (2004). Legal Institutions and Financial Development. NBER Working Paper, No. 10417.

Bernanke, B. S. \& Blinder, A. S. (1992). The Federal Funds Rate and the Channels of Monetary Transmission. American Economic Review, 82 (4), 901-921.

Blum, D. \& Nakane, M. I. (2005). O Impacto de Requerimentos de Capital na Oferta de Crédito Bancário no Brasil. Anais do XXXIII Encontro Nacional de Economia da ANPEC. Natal-BR.

Blundell, R. \& S. Bond (1998). Initial Conditions and Moment Restrictions in Dynamic Panel Data Models. Journal of Econometrics, 87 (1), 115-143.

Calza, A.; Gartner, C. \& Sousa, J. (2001). Modelling the demand for loans to the private sector in the Euro area. ECB Working Paper Series, No. 55.

Calza, A.; Manrique, M. \& Sousa, J. (2003). Aggregate loans to the Euro Area private sector. ECB Working Papers Series, No. 202. 
Cecchetti, S. G. \& Kharroubi, E. (2012). Reassessing the impact of finance on growth. BIS Working Papers, No. 381.

Cottarelli, C.; Dell'ariccia, G. \& Vladkova-Hollar, I. (2003). Early Birds, Late Risers, and Sleeping Beauties: Bank Credit Growth to the Private Sector in Central and Eastern Europe and the Balkans. IMF Working Paper No. $03 / 213$.

De Gregorio, J. \& Guidotti, P. E. (1995). Financial development and economic growth. World Development, 23 (3), 433-448.

Drukker, D. M. (2003). Testing for serial correlation in linear panel-data models. Stata Journal, 3 (2), 168-177.

Freitas, M. C. P. \& Prates, D. M. (1998). Abertura financeira na América Latina: as experiências da Argentina, Brasil e México. Economia e Sociedade, 7 (2), 173-98.

Fritzer, F. \& Reiss, L. (2008). An analysis of credit to the household sector in Austria. Oesterreichische Nationalbank Financial Stability Report, No. 16, 122-34.

Fucidji, J. R. \& Prince, D. D. (2009). Determinantes do Crédito Bancário: uma Análise com Dados em Painel para as Maiores Instituições. Análise Econômica. 27 (52), 233-251.

Greene, W. H. (2018). Econometric analysis. New York: Pearson Education International.

Guo, K. \& Stepanayan, V. (2011). Determinants of Bank Credit in Emerging Market Economies. IMF Working Paper, No. WP/11/51.

Harbo Hansen, N. J. \& Sulla, O. (2013). Credit Growth in Latin America: Financial Development or Credit Boom? IMF Working Paper, No. WP/13/106.

Hicks, J. (1969). A theory of economic history. Oxford: Clarendon Press.

Imran, K. \& Nishat, M. (2013). Determinants of bank credit in Pakistan: A supply side approach. Economic Modelling, 35, 384-390.

Jordà, Ò.; Schularick, M. \& Taylor, A.M. (2010). Financial crises, credit booms, and external imbalances: 140 years of lessons. IMF Economic Review, 59 (2), 340-378.

Kamil, H. \& Rai, K. (2010). The Global Credit Crunch and Foreign Banks Lending to Emerging Markets: Why Did Latin America Fare Better? IMF Working Paper, No. 10/102.

King, R. G. \& Levine, R. (1993). Finance and growth: Schumpeter might be right. The Quarterly Journal of Economics, 108 (3), 717-737.

Levine, R. (1997). Financial Development and Economic Growth: Views and Agenda. Journal of Economic Literature, 35, 688-726.

Levine, R.; Loayza, N. \& Beck, T. (2000). Financial intermediation and growth: Causality and causes. Journal of Monetary Economics, 46 (1), 31-77. 
Mendonça, M. J. \& Sachsida, A. (2013). Identificando a demanda e a oferta de crédito bancário no Brasil. Texto para Discussão No. 1837.

Morales, M. F. (2003). Financial Intermediation in a Model of Growth through Creative Destruction. Macroeconomic Dynamics, 7 (3), 363-393.

Rajan, R. G. \& Zingales, L. (1998). Financial dependence and growth. American Economic Review, 88 (3), 559-586.

Samargandi, N.; Fidrmuc, J. \& Ghosha, S. (2015). Is the Relationship Between Financial Development and Economic Growth Monotonic? Evidence from a Sample of Middle-Income Countries. World Development, 68 (C), 66-81. Schularick, M. \& Taylor, A.M. (2012). Credit booms gone bust: monetary policy, leverage cycles, and financial crises, 1870-2008. American Economic Review, 102 (2), 1029-1061.

Schumpeter, J. A. (1997). A Teoria do Desenvolvimento Económico: uma investigação sobre lucros, capital, crédito, juro e o ciclo econômico. São Paulo: Ed. Abril. Disponible em http://www.ufjf.br/oliveira_junior/files/2009/06/s Schumpeter_-_Teoria_do_Desenvolvimento_Econ\%C3\%B4mico_-_Uma Investiga $\% \mathrm{C} 3 \% \mathrm{~A} 7 \% \mathrm{C} 3 \% \mathrm{~A} 30$ sobre_Lucros_Capital_Cr\%C3\%A9dito_ Juro_e_Ciclo_Econ\%C3\%B4mico.p

Shijaku, G. \& Kalluci, I. (2013). Determinants of Bank Credit to the Private Sector: The Case of Albania. Bank of Albania Working Paper, No. 9 (48).

Vasconcelos, M. R.; Fucidji, J. R.; Scorzafave, L. G. \& Assis, D. L. (2004). O todo e as partes: uma análise da desigualdade de crédito entre os estados brasileiros e os determinantes do crédito bancário com a aplicação de dados em painel. Economia e Sociedade, 13 (1), 123-149.

Vasconcelos, M. R.; Strachman, E. \& Fucidji, J.R. (2003). Liberalização e desregulamentação bancária: motivações, consequências e adaptações. Nova Economia, 13 (1), 101-140.

Wooldridge, J. M. (2002). Econometric analysis of cross section and panel data. Cambridge, Mass.: MIT Press.

Yildirim, H. S. \& Philippatos, G.C. (2007). Restructuring, consolidation and competition in Latin America banking markets. Journal of Banking and Finance, 31 (3), 629-639.

(C) 2020 por los autores; licencia no exclusiva otorgada a la revista Estudios económicos. Este artículo es de acceso abierto y distribuido bajo los términos y condiciones de una licencia Atribución-No Comercial 4.0 Internacional (CC BY-NC 4.0) de Creative Commons. Para ver una copia de esta licencia, visite http://creativecommons.org/licenses/by-nc/4.0 